Original Research Paper

\title{
From the Chicago School to Post-sub Cultural Carriage: A Review and Analysis of Contemporary Trends in Youth Culture Research
}

\author{
Mohd. Aslam Bhat \\ Centre of Central Asian Studies, University of Kashmir, J\&K, India
}

Article history

Received: 10-01-2015

Revised: 30-09-2015

Accepted: 17-02-2016

\begin{abstract}
The historicity of youth culture studies is much challenging to date exactly. Sociologists however, trace its genesis from Chicago School and then leap to Birmingham's Centre for Contemporary Cultural Studies. Theoretically it was, with the works of post subculturists that youth culture research gained ascendency. Global youth culture posture further revamped the field. This paper constructs a critical dialogue between the wide-ranging theories and research on youth culture and global/local relations in this sphere. It is revealed that the current ascendancy of postsubcultural studies margins the significance of sociological research to broader youth queries and does little to extend the case that youth studies should be more sociologically relevant and important. Youth lives in no island of its own and it is not all young people- who have the possibility of engaging in the consumerism, central to some post-sub-cultures. Conversely, youth and their cultures are framed within and to large extent shaped up by social divisions and inequalities. Against this backdrop, it is suggested that youth culture research would prove fruitful only when clubbed with 'transition approach.' Possibly this refit would not only facilitate to widen and thrive the significance of contemporary youth culture studies, rather may help in theoretical sophistication, empirical renovation and a more holistic sociology of youth.
\end{abstract}

Keywords: Youth Culture, Post-Subculture, Chicago School, 'CCCS Approach', Youth Transition, Consumerism

\section{Introduction}

The study of youth cultures has a long-established history. Contemporarily, the most influential work to date has originated from the "Centre for Contemporary Cultural Studies" (CCCS), which was established in the 1970s at Birmingham University. A great deal of the work of CCCS ventured to locate youth sub-cultural movements within a framework of social reaction and resistance against dominant hierarchies of control. Most of these studies identify social class as the main catalyst for the developments of youth sub-cultures. However, this theoretical posture has not escaped criticism, especially with regard to contemporary movements and alternative life-styles. This paper attempts to construct a critical dialogue between the wide-ranging theories and research on youth culture and global/local relations in this sphere. I will begin with a brief description of the historicity of youth culture research. I will then go on to offer an assessment of some work carried out at CCCS. Then I will attempt to offer a conjecture analysis of the theoretical positions engaged with global youth culture, consumerism and cultural fluidity and move onto explain the backdrop of post-subculturists, who consider subcultural identity as 'free-floating signifiers' played away from social structures. But I argue that such a subcultural analysis has never really been of much use in studying youth cultures at large. In the third section, I ask whether we should return to CCCS approach. Finally, I conclude with some observations vis-à-vis the future directions in youth culture research.

\section{Youth Culture: Research Traditions}

Historically, research on youth culture, the culture of young people and the cultural aspects of youthful 
phenomena is much challenging to date exactly. It is however said, that the concept of youth culture (Jugendkultur) was introduced in Germany by Gustav Wyneken (1913/1963). Classically, sociologists but trace the genesis of the concept of youth culture back to the 1920 's with the work of British psychologist Cyril Burt (1929: 29), who carried the Durkheimian notion that delinquency is normal and determined by a multiplicity of causes, involving an interaction between hereditary factors and environmental influences and then sociologists leap to the collection of studies on juvenile delinquency and deviant behaviour produced by social scientists from the Chicago School between the late 1920s and 1960s. The major preoccupations in these studies were subculture in general as opposed to youth subculture in particular and were framed under the structural functionalist methodologies (Gelder and Thornton, 1997: 16). It is at the Chicago School that according to Blackman the first known sociological use of the concept of youth culture was brought in by Palmer (1928). In the aftermath of the Chicago School, the concept became central to American criminology in the late 1950s and 1960s (Palmer, 1928: 1-20).

In this context, Parsons (1942) and (1963), while comprising only two short essays on the subject, are noteworthy and were significant enough in setting the schema for following functionalist understandings of youth culture. He recognized youth culture as marked by 'irresponsibility,' a desire to have a good time and a loose antagonism towards adults; with youth as a time of substantial strain and insecurity brought on by the disengagement from the comfortable existence of childhood and the taking on of adult roles and responsibilities. Equally James Coleman (1961) was not less important in youth cultural studies. Coleman argued that full-time education cuts off adolescents and youth from adult society and isolates them within the educational system. In this state, they develop idiosyncratic elements of exchange with their peers like directing more importance on pleasure over education, peer popularity based on being 'cool,' and an opposing value system to parents- constituting a culture of their own that differentiates them from adult culture. Because, Coleman has used a vast array of research techniques in his work, it was for a long time been considered the main, yet not the only approach in Western sociological literature on adolescents and youth.

There were thus, other diverse and rich conceptualisations around the youth culture in which even the contours of the now familiar concepts can be glimpsed. In this respect the most notable were developmental psychologists, who were to some degree concerned with youth cultural phenomena like Hall (1904), with parallel discussions from ethnographers like
Mead (1928) and Malinowski (1929). Although these works are not imperatively relevant today, however, to explore the concept of youth culture without their reference, not only distorts its historicity, but keeps its tradition down. In fact scholars like Musgrove (1964: 2) and Savage (2008) cast Hall's work as the first significant academic study of the concept of youth and youth culture. Hall (1904: 72) put forward that 'for the complete apprenticeship to life, youth needs repose, leisure, art, legends, romance and idealization [...].'

\section{Concept and Theory of Youth Culture in 1960s and 1970s}

Having had received a wide currency in social science research, it was in the late 1960's however, that 'youth culture' became a widespread, massive and commercialized phenomenon. Some scholars insist that the model of the 'teenager' that evolved in the early $20^{\text {th }}$ century received cultural importance in the post-World War II economy of growth and affluence, where young middle-class consumers were freed from wage-earner responsibilities (Bennett, 1999: 231-32). Again the country, where these developments were first experienced was United States, as Savage (2008: 465) observes that 'the post-war spread of American values would be spearheaded by the idea of the Teenager. This new type was the ultimate psychic match for the times: Living in the now, pleasure-seeking, product hungry global society, where social inclusion was to be granted through purchasing power.' Resultantly a new music and a dance style of rock, movies, cars and a mass produced teenage fashion emerged. According to Matza (1961: 145 ) the three major forms of youth culture that surfaced during this period in American society were:

- Juvenile Delinquency: Characterised by a spirit of adventure, disdain of work and aggression.

- Radicalism: Characterised by mundane political activity and guided by apocalyptic vision- belief that the evil world... full of temptation and corruption... will be replaced by a purer and better world, populism-belief in the creativity and superior worth of the ordinary people, of the uneducated and unintellectual and evangelism-excursions made by sectarians to the outside world for the purpose of recruiting sympathisers, supporters and members.

- Bohemianism: Seen as 'socio-artistic' in character. Matza considers Romanticism- an appreciation of the spontaneous manifestations of the essence of concrete individuality, Monasticism- communities of authentic adherents and Bohemian Mood-mood not to be suppressed or obscured, rather it is to be indulged, pursued and exhibited, as the persistent components of Bohemianism. 
With these experiences American sociologists produced a good volume of research around youth revolts, new life-styles and generational changes. However, closely as American music in the 1960s was outshined by the British beat, led by the beatles and the rolling stones, slightly the same resulted a few years later in field of youth culture research (Forans and Bolin, 1995: 5). In the second half of the 1970s, the British researchers associated with the Centre for Contemporary Cultural Studies (here after CCCS) at University of Birmingham fashioned a series of highly influential works on youth culture phenomenon. Specifically, the works by McRobbie and Garber (1975), Hall and Jefferson (1975), Willis (1990), McRobbie (1978) and Corrigan (1979) were to prove formative for what became the new field of youth sub-cultural studies (Griffin, 2011). All-through these scholarships at CCCS, the psychological canon of the concept of subculture was contested, as Blackman (2005: 5) writes:

[..] and in an attempt to break the association of subculture with pathology Cohen (1972, p. 30) argued that it is 'important to make a distinction between subculture and delinquency'. The twin ideas Cohen introduced to subculture were 'imaginary relations' and 'magical solutions', through an Althusserian reading of Jacques Lacan's concept of the 'imaginary' and Claude LeviStrauss's concept of 'myth' (Cohen, 1997, pp. 48-50). Using one of Louis Althusser's theories of ideology as a 'real' and unconscious force seducing people via hidden determinations, he rearticulated Levi-Strauss (1962/1966) theory of myth into an explanation of how subcultures magically resolve social contradictions through multiple narratives of bricolage in the form of style, symbols and ritual.

Even if more diverse than it occasionally is given credit for, the CCCS's work on youth culture was for the most part embraced by an analysis, centered on the appraisal of sub-cultural styles especially Teds, Rockers, Mods and Skinheads as a group-centered articulation of youth resistance to working-class structural marginalisation and social change in post-war Britain (Geldens et al., 2011: 348). A more sophisticated, neo-Marxist, class-based theory of working-class sub/cultural resistance was developed (e.g., Resistance Through Ritual (RTR), with the majority of arguments drawn from the sociology of deviance to counter the descriptions of these young people as criminal, deviant and a threat to the status $q u o$, applying ethnographic evidences to counter the panic-fuelled media accounts, with young people's narratives of specific events (Hall and Jefferson, 1975: 149-50). Essentially working-class youth sub/cultures were seen as 'social formations constructed as a collective response to the material and situated experience of their class' (Clarke et al., 1976: 47). Hence, the elementary postulation in CCCS works was that youth sub/cultures belong to the working class youth, stemming from the experience of subordination. Youth sub/cultural activity was therefore, understood as a form of symbolic politics and resistance to specific cultural and class experiences.

In the late 1980s, however, the domination that 'CCCS approach' enjoyed for sometime was countered by extensive and subsequent criticisms. Particularly due to some theoretical and methodological inconsistencies, coupled with issues like rising youth unemployment rates related to comprehensive social and economic changes in intervening years, this approach began to be referred in derogatory terms as an orthodoxy and was replaced by 'second wave' of British youth research- 'postsubcultural studies' (Roberts, 2005: 4). Inspired by the increasingly emerging brainwave of postmodernism and post-structuralism, the postsubcultural studies posed an acute set of protestations to the grand narratives of 'CCCS approach' (a point to which I shall return in next section) and were largely engaged with the discussions of dance cultures, music and young styles and by and large dominated by diverse 'cultural' discriptions of young people's lives' (Nayak, 2003: 306). Feminists also criticized the 'CCCS approach' for being prejudiced - carrying forward the experiences of young men only - and therefore, argued that it doesn't proffer much consideration to misogyny, homophobia and problematic masculinism in the studies of subcultures (Frosh et al., 2002: 53). Consequently, the youth researchers engaged with theories of globalisation and the conception of global youth culture(s) also "turned the academic gaze away from the stylistic appearances of particular tribes and the stylistic art of a few toward the transitions to adulthood", carved out by young people in deteriorated economic situations (Clarke, 1982: 349-55). Though, currently certain important continuities in classical youth culture research have been brought to the forefront, (Hodkinson, 2002; Nayak, 2003) the 'transition approach', however, dominate the field of youth studies. In what follows, I will attempt to offer a conjecture analysis of the theoretical positions engaged with global youth culture, consumerism and fluidity and, explain the backdrop of Post-subculturists. 


\section{Globalisation, Consumer Society and the Post-subculture Debate}

Arguably, the indispensable economic, cultural and social movement of the preceding half century continues to be globalisation- where "people, information, money and technology all flow around the globe in a rather chaotic set of disjunctive circuits that somehow bring us all together" (Friedman, 2008: 111). Harvey (1989: 292) refers to this 'togetherness' as 'time-space compression'- the way the world has in effect been deterritorialised by the acceleration and wider dissemination of capitalistic practices or what Giddens (1991: 4) suggests 'the intensification of worldwide social relations which link distant localities in such a way that local happenings are shaped by events occurring many miles away and vice versa.'

Admittedly in this vista of change, many sociologists, human geographers and politico-economists have portrayed youth as being at the forefront, or generally considered as the diligent consumer of the global. As Wulff (1995: 10) has argued 'when it comes to globalisation or transnational connections, youth cultures are in the forefront of theoretical interest. Youth, their ideas and commodities move easily across national boundaries, shaping and being shaped by all kinds of structures and meanings.' Indeed some scholars argue that youth culture simultaneously shapes globalisation and in turn is shaped by it, while others held that youth culture is the 'vehicle for globalisation' (Dean, 2000). In this respect Lukose (2005: 915) points out that 'a short-hand way to mark the advent and impact of globalisation is to point to the evidence of 'global' youth consuming practices.' It is this practice, which is interconnected to the emergence of a 'global youth culture,' (Pilkington, 1997: 147-66) wherein young people- at least the middle class ones, go for samilar slang expressions, hair styles, clothing and listen to some of the same music.

Cultural subtext is therefore, vital to understanding human side of globalisation and unsurprisingly youth culture will have substantial bearing on its future, because youth is a 'social shifter' (Durham, 2004: 589-605) and a stage of strong change of life, characterised by 'open psychic structures,' when one is wide open to all sorts of influences and curious to test out everything- even the forbidden (Kristeva, 1990: 49-50). This character of youth may comprise one of the major reasons accounting for why youth are more open and receptive of growing up within this milieu of cultural multiplicity and change. Nevertheless, the major aspect of globalisation that directly affects youth and has a number of implications for youth cultures is global consumerism and it is well established that in many youth cultures, access to goods and wealth is pivotal for attaining respect and making and controlling money symbolises freedom and power (see Hemmings, 2002; Milner, 2004; Deutsch and Theodorou, 2010).

In his Common Culture, Willis (1990) in contrast to the 'sub-cultural approach of CCCS' (according to him 'CCCS approach' misses to understand the complex interaction of young peoples' cultural practices with the 'mainstream culture') argues that young people utilise commodities to creative ends besides their meaning within the circulation of capital, asserting that for young people this is a question of 'cultural survival.' He insinuates that within the structural vacuum of late modernity, youth's symbolic work and creativity are means to both maintain traditional identities and to evolve alternative ones. Willis thus underlines that young people's everyday life in late modernity is suffused with symbolic work and creativity, signifying that this potential is exploited most appropriately in their practices of consumption (pp. 6-21). Equally, Thornton (1995) and Gilbert and Pearson (1999) also make out that how cultural practices are situated in a broad [here for instance global] cultural field, which entails larger processes of consumption, production etc. and proffer diferent models for grasping the links between youth culture and 'mainstream' commercial culture. Intrinsic to their arguments is the consideration how young people are engrossed in a complex relationship with consumption, owing to which they actively interpret and create their own sets of cultural experiences.

Generally this consumption by youth is understood to be celebrated out in a set of awfully stylised amphitheaters of music, clothing, social media, food, drugs and drinks (Kjeldgaard and Askegaard, 2006: 233). The impact of these amphitheaters further amplified by factors such as expansion of education and changes in the benefit system together is seen to have homogenized youth cultural globally.

The consumption and leisure in youth culture are therefore, considered both as the lynchpin of cohesion to youth segment and the source of individual identity, playing a significant role in defining who you are and your experience and consciousness. Hall and Jefferson (2006: vii-xxxii) articulate this youth cultural shift as both a response to and an attempt at 'magical resolution' of recent transformations in late capitalism, which include the development of mass consumption, the deindustrialisation of the Anglo-American world, the commercialisation of culture and the emergence of the New Right, together which characterize the neo-liberal social order. Since, neo-liberalism promotes selfdisciplined, individualised entrepreneurial techniques of governmentality- what Bourdieu (1984: 50) calls 
'knowledge without concepts,' where the social order is progressively inscribed in people's minds.' Recurrently in this social order, youth is conceptualised as to stand for an in process identity, acted out at the individual level (O'Donnell and Wardlow, 1999: 13-8) as well as at a cultural level (Forans and Bolin, 1995: 1-10). Specifically on the side of market ideology of this order:

\section{[...] youth are certainly [considered] avid consumers of global cultural industry products and services. This forms such an important part of the cultural practice of young people everywhere that, worldwide, youth is a market 'potentially twice the size of China' [...]. Through the 'new' media, youth [...] are central to the global leisure market, not just the 'marketing focus' for cultural industry innovations, but the source of their inspiration. CEOs send 'cool-hunters' down to the street and to public places where young people gather to find the 'new' look and sound, the avant-garde trend, which global cultural industries can then commodify, regularize and market [...] in the process [..] described as McDonaldisation (Nilan and Feix, 2006: 8).}

In its dystopian expression, this extract provides some rough spots of Beck's notion of techno-economic progress wherein an individual is politically disengaged and instead, co-opted into market ideologies linked with neo-liberal economic logic, de-territorialised transnational corporate capitalism and rampant consumerism (Beck and Johannes, 2004: 128). Broadly, it is against the backdrop of this neo- liberal 'supermarket of style' (Polhemus, 1997: 402) stuffed with its themed fantasy world of excessive pleasureseeking and forceful consumer power (Chatterton and Hollands, 2003: 175) that the concepts such as, clubcultures (Thornton, 1995), post sub-cultural identities (Muggleton, 1997), neo-tribes (Bennett, 2000), lifestyles (Miles, 2000), scenes (Stahl, 2004) and cyber-cultures and so on emerged increasingly, revealing some specific area of global youth cultural trends. I have not engaged with these concepts in an extensive detail here, partly because they have been already taken to length in a range of other texts. Arguably in the whole field of these studies, youth cultures are interpreted as the cutting edge of an increasingly post-modernity and members of this supposedly postmodern youth group are considered less overtly political and confrontational than those of past [CCCS] sub-cultural generations.

In this connection Muggleton and Weinzierl (2003: 7-8) insist that 'the explicitly political agenda of the
CCCS- to discover forms of rebellion in working-class youth movements- led them to underemphasize the extent of sub-cultural participation in economic processes. In fact, subcultures were theorized as rebelliously 'political' by virtue of their ritualistic resistance to capitalist incorporation.' Similarly Stahl (2003: 27-42) assumes that due to the heroic rhetoric of ritualistic resistance, the sartorial appeal of mods, teds, punks and rockers became illustrative of a 'semiotic guerrilla warfare,' which took objects from the mainstream culture and incorporated their usual naturalised reference into something spectacular and alien. Style therefore, developed into a form of resistance and the over emphasis on a linear model, for instance, holding social class determinative in the origins of sub-cultural practices, excluded other variables like age, gender, ethnicity. Such an emphasis down played the consideration of these factors to outside the purview of a model bound to a geographically specific notion of territory and 'winning space'. Indeed following Redhead (1995)- who extensively drew from Jean Baudrillard's notion of the 'end of the social' to refute the CCCS radical tradition, Muggleton (2000: 47-8) further takes the postmodernist accounts and defines post variety subculturalists as revelling in choice, 'no longer articulated around... the structuring of class, gender or ethnicity.' Hence, Muggleton considers sub-cultural identity as 'free-floating signifiers' played away from social structures. On such footing, Muggleton makes a point that 'there are no rules' for sub-cultural identities and there are no authentic sub-cultures, because he claims that contemporary society is post-modern and that the breakdown of mass society has ensured that there is no longer a coherent dominant culture against which a subculture can express its resistance.

Equally following Michel Maffesoli (1996), Sweetma (2009) and Bennett and Kahn-Harris (2004) suggest that the subculture as a concept could be reconsidered in connection with concept of tribalism. As Bennett argues that subcultures could be thoughtout as 'neotribes'- a type of relatively loosely defined collectivities, which individuals can choose to participate in for a period of time. Altogether, these scholarships utilise the concept of tribalism as a way of analyzing how young people form temporary alliances and move from site to site, looking for alternative identities through their membership in loose friendship networks or by attending new cultural events and groups.

Generally speaking, the post variety subculturalists are adamant of the possibility of seeing sub-cultures as fluid, fragmented and multifaceted, with consumption rather than resistance as the hallmark of analysis and it is argued, that today there 
is a possibility that individuals can flow in and out of a series of sub-cultures or join up several subcultures simultaneously. This shift in youth culture studies has been significantly determined by developments in general social theory. Whether under the remit of the condition of post-modernity, 'risk society' or individualisation thesis, post variety social theories authenticate that:

Increasingly everyone has to choose between options, including as to which group or subculture one wants to be identified with. In fact one has to choose and change one's social identity as well and take the risks in doing so (Beck, 1992: 88).

The basic scholarships in this discourse have recurrently accentuated the breakdown of traditional forms of certainty, stability and continuity, combined with the simultaneous expansion and diversification of media and consumer culture. Fluidity, fragmentation, risk and de-standardisation are seen in the ascendant, which tend to downplay the significance of social structural influences on youth culture. I don't want to rehearse this widely debated theme herein. It is however; worth mentioning that post variety subcultural theories don't go unnoticed. Alongside the diversity of approach in youth culture research, there are currently an increasing number of researchers, who seek to draw from the strengths of all these traditions. One result has been highly complex trans-local youthful identities, often understood as 'hybrid' (see Nilan and Feixa, 2006). Secondly, since the claims of contemporary irrelevance of class ring void given the increasingly escalating gap between the rich and the poor in a context where social inequalities still seem to follow predictable patterns (Evans, 2007) and social mobility rates are almost static (Paxton and Dixon, 2004), there has been renewed interest in class analysisin relation to the constitution of economic classes, the casual effects of class situations, the formation of social class and patterns of class awareness (Scott, 2002). Much of this revisionist work has been influenced by Bourdieu, whose approach may be seen as blending, through his conceptual trilogy of field, capital and habitus, both economic and symbolic (cultural) forms of social differentiation and inequality. Expressly, in some recent sociologies of youth (Adams, 2006), Bourdieu's original theorising, particularly his practice theories and the concept of habitus has been applied as an important analytic tool to understand the continuing inequalities. In this whole discourse, extensive revisions in the sphere of cultural studies are being made to the conceptual vocabulary of the 'CCCS approach.'

\section{Reviving the 'CCCS Approach'}

Hodkinson's (2002) Goth: Identity, Style and Subculture, is the best illustration vis-à-vis reviving the CCCS approach. Hodkinson defends the term subculture and suggests that it can be used to refer to relatively distinctive lifestyle groupings, which are crucial to their members' sense of identity and to which their members display a greater level of commitment. Even if, acknowledging that media and commerce play a significant part in the development of subcultures, he argues that the concept is still relevant and applicable, however needs to be rethought in view of many of its previous connotations (Sweetma, 2009). Concomitantly numbers of scholars have argued for the continued significance of structural categories, particularly 'social class,' to the study of youth sub-cultures. They argue that despite the marked variation in dressing, musical preferences and language etc. youth however, live in no island of its own. Youth and their cultures are framed within and to large extent shaped up by social divisions and inequalities.

In this perspective, Jensen (2006) and Shildrick and MacDonald (2006) are the prominent readings, which bring forth that it is not all young people- who have the possibility of engaging in the consumerism, central to some sub-cultures. Rather, as Shildrick and MacDonald argue, there are clear social demarcations evident in the cultural lives of young people that arise from both wider social divisions and lifestyle segmentations. There is insinuation that the current ascendancy of post-subcultural studies margins the significance of sociological research to broader youth queries and does little to extend the case that youth studies should be more sociologically relevant and important (Shildrick and MacDonald, 2006). They therefore, propose the 'CCCS approach' to grasp, not merely the links between culture and social structure and the ways in which young people's biographies evolve out of this relationship, instead Shildrick and MacDonald are contended that this approach still is a valuable one for the sociology of youth.

In this line of thought a consistent reminder of the continuing stabilities and fixities related with factors like locality, race and place come from Nayak (2003), Pilkington and Johnson (2003) and Pilkington (2004). They insist that not all young people share equally in the contemporary global youth culture. Nayak's (2004) highlights three types of youth culture among the racially white English. The demonstration of these white youth cultures corresponds to the author's classification of three cultural responses to globalisation- localist, survivalist and globalist. These responses offer enough evidence to challenge the 
representation of a 'shrinking world' as suggested by the concept of globalisation and exemplify the continuing relevance and significance of locality in the development of cultural identity.

Hence, while globalisation increases cultural access across territorial lines, local processes, nevertheless remain important in the development of cultural identities. It is possibly against this backdrop that Pilkington and Johnson (2003) have criticized some post-modernist's commentaries of globalised youth culture, for they prioritize 'taste communities' over and above the place-based, 'real communities.' Pilkington and Johnson rather point to the continued relevance of markers of identity formed around global/local relations of ethnicity, race, gender, class, sexuality and generation. Specifically, build on a long-standing research interest in Russian youth, Pilkington (2002) and Blum (2007) introduced the study of youth and globalisation in the Former Soviet Union (FSU). While Blum formulated cultural globalisation in terms of 'hybridisation,' Pilkington however, challenged the notion of hybridity. Making a point that young people engage in a 'parallel reception' of the global and local cultural ideas and products instead of synthesizing them, Pilkington insists, 'while young Russians aspire to Western standards of living... they don't seek to emulate Western standards of "being," and where spiritual life is concerned, young people remain firmly rooted to the local' (Pilkington, 2002: 10-20). Precisely Pilkington (2004) considers how global cultural ideas and products articulate with local circumstances to help generate 'youth cultural strategies' that are evolved-out of the social cleavages of Soviet modernity. In so doing, she presents two broad-based youth cultural categories: The 'progressives' (West-looking, global, stylistic) and the 'normals' (ordinary, local and mainstream).

Such an endeavor not only offers a sophisticated theoretical approach, but it proffers a corrective to youth studies that are only based on Western European, British and North American research. Pilkington therefore, argues that the theorisation of youth culture in its local, national and international context is likely to be valuable than a narrowly sub-cultural focus on style and consumption. Obviously in this perspective globalisation theory can provide a valuable basis for dialogue within youth cultural studies, not in the sense that there exists a uniform global society. Rather, such an approach would enable scholars to resist the assumption that there is a uniform global society and that cultural influence by and large occur in one direction i.e., from 'core' to 'periphery'. Resultantly this would enable researchers to devise ways of relating 'micro-empirical' studies of youth culture to wider social structures (Pilkington, 1997: 159-63).

\section{Conclusion: Future Directions in Youth Culture Research}

Having constructed a dialogue between a wideranging theories and research on youth culture and global/local relations in this sphere, it is revealed that the current ascendancy of post-subcultural studies margins the significance of sociological research to broader youth queries and does little to extend the case that youth studies should be more sociologically relevant and important. And largely discount the political, resistant, sub-cultural character of their subject. Youth lives in no island of its own and it is not all young people- who possess appropriate means and access to engage in the consumerism, central to some post-sub-cultures. Instead, there are clear social demarcations evident in the cultural lives of young people that arise from both wider social divisions and lifestyle segmentations. Youth and their cultures are thus framed within and to large extent shaped up by social divisions and inequalities inherent in societies and countries across the world.

Against this backdrop, for methodological and conceptualisation purposes, I propose Beck and BeckGernsheim (2009) notion of 'global generation'- a generation comprising not only of those who buy and live with consumer brands and images and those who are unable to buy and live with these symbols, but also those who risk their lives to become migrants to the consumer paradises of the Western World or gulf countries. Beck then proposes a cosmopolitan sociology, which takes globality and social life on planet Earth seriously with its all diversity in order to understand the conditions, divisions, contradictions, desires and impacts of this global generation. Here, in essence $\mathrm{I}$ aim at a 'sociological imagination' to inform the discourse on youth culture- to say we have to look at the person in the situation, in the historical context and ask how they are using all the available resources that they have to make meaning and to give dignity and worth to their existence.

In this context, I contend that in the tradition of youth culture studies, the core schema of the 'CCCS approach' is still relevant to study the relationship between culture and social structure and the ways in which young people's biographies evolve out of this relationship. However, in view of the current ascendency of 'transition approach' certain reformulations in 'CCCS approach' such as combining cultural and structural analysis would not only facilitate to widen and thrive the significance of contemporary youth culture studies, rather may help in theoretical sophistication, empirical renovation and a more holistic sociology of youth. As Shildrick and MacDonald (2006) argue that youth cultural studies, particularly the 'post-subcultural studies' may prove to be more inclusive and holistic if a closer attention is paid to questions of transition and of 
social divisions. Specifically, examination of culture based identities and activities within the preview of youth transition studies may help bridge the analytical divide between the tradition of youth 'transition approach,' which largely skips issues of culture, leisure, identity etc. and youth 'culture approach.'

\section{Acknowledgement}

I would like to thank two anonymous referees for their advice and suggestions.

\section{Ethics}

There are no foreseen ethical implications of the article. The article is a review and did not require ethical approval.

\section{References}

Adams, M., 2006. Hybridizing habitus and reflexivity: Towards an understanding of contemporary identity? Sociology, 40: 522-525. DOI: $10.1177 / 003803850663672$

Beck, U. and E. Beck-Gernsheim, 2009. Global generations and the trap of methodological nationalism for a cosmopolitan turn in the sociology of youth and generation. Eur. Sociol. Rev., 25: 2536. DOI: $10.1093 /$ esr/jen032

Beck, U. and W. Johannes, 2004. Conversations with Ulrich Beck. 1st Edn., Wiley, Cambridge, ISBN-10: 0745628249, pp: 240.

Beck, U., 1992. Risk Society: Towards a New Modernity. 1st Edn., SAGE Publications, London, ISBN-10: 0803983468, pp: 206.

Bennett, A. and K. Harris, 2004. After Subculture: Critical Studies in Contemporary Youth Culture. 1st Edn., Palgrave Macmillan, ISBN-10: 0333977114, pp: 195.

Bennett, A., 1999. Popular Music and Youth Culture: Music, Identity and Place. In: Kjeldgaard, D. and S. Askegaard, 2006. The glocalisation of youth culture: The global youth segment as structures of common difference. J. Consumer Res., 33: 231-32.

Bennett, A., 2000. Popular music and youth culture: music identity and place, Macmillan. London.

Blackman, S., 2005. Youth subcultural theory: A critical engagement with the concept, its origins and politics, from the Chicago school to postmodernism. J. Youth Stud., 8: 1-20.

Blum, D.W., 2007. National Identity and Globalization: Youth, State and Society in Post-Soviet Eurasia,1st Edn., Cambridge University Press, ISBN-10: 9780521876193, pp: 234.

Bourdieu, P., 1984. Distinction. In: Threadgold, S. and P. Nilan, 2009. Reflexivity of contemporary youth, risk and cultural capital. Curr. Sociol., 57: 50-50.
Burt, C., 1929. The psychology of the bad child. In: Brake, M., 1980. The Sociology of Youth Culture and Youth Subculture: Sex and Drugs and Rock 'N' Roll? 1st Edn., Routledge, London, pp: 29.

Chatterton, P. and R. Hollands, 2003. Urban Nightscapes: Youth Cultures, Pleasure Spaces and Corporate Power. 1st Edn., Routledge, London, ISBN-10: 0415283469, pp: 304.

Clarke, G., 1982. Defending Ski-jumpers: A Critique of Theories of Youth Sub-cultures. In: Shildrick, T. and R. MacDonald, 2007. Street corner society: Leisure careers, youth (sub) culture and social exclusion. Leisure Stud., 26: 349-355.

Clarke, J., S. Hall, T. Jefferson and B. Roberts, 1976. Subcultures, Cultures and Class. In: Resistance through Rituals, Hall, S. and T. Jefferson, (Eds.), Hutchinson, London, ISBN-10: 0091279119.

Cohen, P., 1997. Rethinking the Youth Question. 1st Edn., Macmillan, London.

Cohen, P., 1972. Subcultural conflict and working class community. Working Papers in Cultural Studies, CCCS, University of Birmingham.

Coleman, J., 1961. The Adolescent Society: The Social Life of the Teenager and its Impact on Education. In: Youth Culture in Late Modernity, Forans, J. and Bolin, G. (Eds.) London, Sage.

Corrigan, P., 1979. Schooling the Smash Street Kids. 1st Edn., Macmillan, London.

Dean, C., 2000. We Aren't the World- Princeton Project on 'Globalisation. Youth and Religion,'.

Deutsch, N.L. and E. Theodorou, 2010. Aspiring, consuming, becoming: Youth identity in a culture of consumption. Youth Society, 42: 229-252. DOI: $10.1177 / 0044118 X 09351279$

Durham, D., 2004. Disappearing youth: Youth as a social shifter in Botswana. Am. Ethnol., 31: 589-605. DOI: 10.1525/ae.2004.31.4.589

Evans, K., 2007. Concepts of bounded agency in education, work and the personal lives of young adults. Int. J. Psychol., 42: 85-93. DOI: $10.1080 / 00207590600991237$

Forans, J. and G. Bolin, 1995. Youth Culture in Late Modernity. 1st Edn., Sage Publications, London, ISBN-10: 0803988982, pp: 198.

Friedman, J., 2008. Global Systems, Globalization and Anthropological Theory. In: Frontiers of Globalization Research: Theoretical and Methodological Approaches, Rossi, I. (Ed.), Springer Science and Business Media, New York, ISBN-10: 038733596X, pp: 109-132.

Frosh, S., A. Phoenix and R. Pattman, 2002. Young Masculinities. 1st Edn., Palgrave Macmillan, Basingstoke, ISBN-10: 1403914583, pp: 304.

Geldens, P., S. Lincoln and P. Hodkinson, 2011. Editorial: Youth, identities, transitions and cultures. J. Sociol., 47: 347-353. DOI: $10.1177 / 1440783311420786$ 
Gelder, K. and S. Thornton, 1997. The Subcultures Reader. 1st Edn., Psychology Press, Routledge, ISBN-10: 0415127270, pp: 599.

Giddens, A., 1991. Modernity and Self-Identity: Self and Society in the Late Modern Age. Ist Edn., Stanford University Press, Stanford, Calif., ISBN-10: 0804719446, pp: 256.

Gilbert, J. and E. Pearson, 1999. Discographies: Dance Music, Culture and the Politics of Sound. 1st Edn., Routledge, London, ISBN-10: 0415170338, pp: 195.

Griffin, C., 2011. The Trouble with class: Researching youth, class and culture beyond the 'Birmingham school'. J. Youth Stud., 14: 245-259.

DOI: $10.1080 / 13676261.2010 .533757$

Hall, S. and T. Jefferson, 1975. Resistance through Rituals: Youth Subcultures in Post-war Britain, [RTR]. In: Griffin, C., 2001. Imagining new narratives of youth: Youth research, the 'New Europe' and global youth culture. Childhood, 8: 149-50.

Hall, S. and T. Jefferson, 2006. Once More around 'Resistance through Rituals. In: Resistance through Rituals, Hall, S. and T. Jefferson (Eds.), Routledge, London, pp: 7-32.

Hall, S., 1904. On Adolescence: Its Psychology and its Relation to Physiology, Anthropology, Sociology, Sex, Crime, Religion and Education. In: Savage, J., 2007. Teenage: The Creation of Youth Culture. 1st Edn., Chatto and Windus, London, pp: 72.

Harvey, D., 1989. The Condition of Post-modernity. In: UN, 2003. World Youth Report, 2003. UN, Department of Economics and Social Affairs, United Nations.

Hemmings, A., 2002. Youth culture of hostility: Discourses of money, respect and difference. Qualitative Stud. Educ., 15: 291-307.

DOI: $10.1080 / 09518390210122836$

Hodkinson, P., 2002. Goth: Identity, Style and Subculture. 1st Edn., Berg, Oxford, ISBN-10: 185973605X, pp: 288.

Jensen, S.Q., 2006. Rethinking subcultural capital. Young, 14: 257-276. DOI: $10.1177 / 1103308806065820$

Kjeldgaard, D. and S. Askegaard, 2006. The Glocalization of youth culture: The global youth segment as structures of common difference. J. Consumer Res., 33: 231-247. DOI: 10.1086/506304

Kristeva, J., 1990. The Adolescent Novel. In: Youth Culture in Late Modernity, Forans, J. and G. Bolin (Eds.), Sage, London, pp: 49-50.

Levi-Strauss, C., 1962/1966. The Savage Mind. Weidenfield and Nicholson, London.

Lukose, R., 2005. Consuming globalization: Youth and gender in Kerala, India. J. Social History, 38: 915-935. DOI: $10.1353 /$ jsh.2005.0068
Maffesoli, M., 1996. The Time of the Tribes: The Decline of Individualism in Mass Society. 1st Edn., SAGE Publications, London, ISBN-10: 080398474X, pp: 176.

Malinowski, B., 1929. The sexual life of savages in north-western Melanesia. In: Bucholtz, M., 2002. Youth and Cultural Practice. Ann. Rev. Anthropol., 31: 525-525.

Matza, D., 1961. Subterranean Traditions of Youth. In: Gandhi, P.K., 1983. Rural Youth in Urban India. Seema Publications, Delhi.

McRobbie, A. and J. Garber, 1975. Girls and Subcultures: An Exploration. In: Resistance Through Rituals, Hall, S. and T. Jefferson (Eds.), Hutchinson, London, pp: 209-222.

McRobbie, A., 1978. Working class girls and the culture of femininity. In: Women Take Issue: Aspects of Women's Subordination, Women's Studies Group, (Ed.), Hutchinson, London, pp: 96-108.

Mead, M., 1928. Coming of Age in Samoa: A Psychological Study of Primitive Youth for Western Civilisation. In: Stephenson, R.A., 1998. Crosscultural studies of contemporary Youth. Curr. Anthropol., 39: 181-182.

Miles, S., 2000. Youth Lifestyles in a Changing World, Open University Press, Buckingham.

Milner, M., 2004. Freaks, Geeks and Cool Kids: American Teenagers, Schools and the Culture of Consumption. 1st Edn., Routledge, London, ISBN-10: 0203484835, pp: 320.

Muggleton, D. and R. Weinzierl, 2003. The Postsubcultures Reader. 1st Edn., Bloomsbury Academic, New York, ISBN-10: 1859736688, pp: 324.

Muggleton, D., 1997. The Post-Subculturalists. In: The Club Culture Reader, Redhead, S. (Ed.), Blackwell, Oxford, pp: 185-203.

Muggleton, D., 2000. Inside Subcultures: The Postmodern Meaning of Style. 1st Edn., Bloomsbury Academic, ISBN-10: 1859733476, pp: 224.

Musgrove, F., 1964. Youth and Social Order. 1st Edn., Routledge, London, ISBN-10: 0710062109, pp: 165.

Nayak, A., 2003. Ivory lives: Economic restructuring and the making of whiteness in a post-industrial youth community. Eur. J. Cultural Stud., 6: 306-325. DOI: $10.1177 / 13675494030063003$

Nayak, A., 2004. Race, Place and Globalization: Youth Cultures in a Changing World. 1st Edn., Bloomsbury Academic, New York, ISBN-10: 1859736041, pp: 256.

Nilan, P. and C. Feixa, 2006. Global Youth?: Hybrid Identities, Plural Worlds. 1st Edn., Routledge, London, ISBN-10: 1134198345, pp: 232. 
O'Donnell, K. and D. Wardlow, 1999. A theory on the origins of coolness. Adv. Consumer Res., 27: 13-18.

Palmer, V.M., 1928. Field Studies in Sociology: A Student's Manual. 1st Edn., University of Chicago Press, Chicago, pp: 281.

Parsons, T., 1942. Age and sex in the social structure of the united states. Am. Sociol. Rev., 7: 604-616.

Parsons, T., 1963. Youth in the Context of American Society. In: Youth: Change and Challenge, Erikson, E. (Ed.), Basic Books, New York,

Paxton, W. and M. Dixon, 2004. The State of the Nation: An Audit of Injustice in the UK. 1st Edn., Institute for Public Policy Research, London, pp: 68.

Pilkington, H. and R. Johnson, 2003. Peripheral youth: Relations of identity and power in global/local context. Eur. J. Cultural Stud., 6: 259-283. DOI: $10.1177 / 13675494030063001$

Pilkington, H., 1997. Is there a Global Youth Culture? A View from the Periphery. In: Griffin, C., 2001. Imagining new narratives of youth: Youth research, the 'new Europe' and global youth culture. Childhood, 8: 147-66.

Pilkington, H., 2002. Looking West? Cultural Globalization and Russian Youth Cultures. 1st Edn., Penn State Press, USA, ISBN-10: 0271021861, pp: 300.

Pilkington, H., 2004. Youth Strategies for Global Living: Space, Power and Communication in Everyday Cultural Practice. In: After Subculture: Critical Studies in Contemporary Youth Culture, Bennett, A. and K. Kahn-Harris (Eds), Palgrave Macmillan, Basingstoke, ISBN-10: 0333977114.

Polhemus, T., 1997. In the Supermarket of Style. In: The Clubcultures Reader, Redhead, S., D. Wynne and J. O'Connor (Eds.), Blackwell Publishers, Cambridge, ISBN-10: 0631197869.

Redhead, S., 1995. Unpopular Cultures. In: Blackman, S., 2010. Youth subcultures, normalisation and drug prohibition: The politics of contemporary crisis and change. British Polit., 5: 354-55.

Roberts, K., 2005. What ${ }^{\text {ee }}$ s the point in studying youth cultures? Proceedings of the Annual British Sociological Association Conference. In: Shildrick, T. and R. MacDonald, 2006. Defense of subculture: young people, leisure and social divisions. J. Youth Stud., 9: 4-4.

Savage, J., 2008. Teenage: The Creation of Youth Culture. 1st Edn., Pimlico, London, ISBN-10: 1845951468, pp: 551.

Scott, J., 2002. Social class and stratification in late modernity. Acta Sociol., 15: 23-35.

DOI: $10.1177 / 000169930204500103$

Shildrick, T. and R. MacDonald, 2006. In defence of subculture: Young people, leisure and social divisions. J. Youth Stud., 9: 125-140. DOI: $10.1080 / 13676260600635599$
Stahl, G., 2003. Tastefully Renovating Sub-Cultural Theory: Making Space for a New Model. In: The Post-Subcultures Reader, D. Muggleton and R. Weinzierl (Eds.), Berg, New York, ISBN-10: 1859736637, pp: 27-42.

Stahl, G., 2004. 'It's like Canada reduced': Setting the scene in Montreal. In: After Subculture: Critical Studies in Contemporary Youth Culture, Bennett, A. and K. Kahn-Harris (Eds.), Palgrave, Basingstoke, pp: 51-64.

Sweetma, P., 2009. Subculture: Hodkinson's Goth. In: Doing Social Science: Evidence and Methods in Empirical Research, Devine, F. and S. Heath (Eds.), Palgrave Macmillan, New York, ISBN-10: 1137020547.

Thornton, S., 1995. Club cultures: Music, media and sub-cultural capital. In: Gilbert, J. and E. Pearson, 1999. Discographies: Dance Music, Culture and the Politics of Sound. Routledge, London, pp: 160.

Willis, P., 1990. Common Culture: Symbolic Work at Play in the Everyday Cultures of the Young. 1st Edn., Open University Press, Milton Keynes, ISBN-10: 0335094325, pp: 165.

Wulff, H., 1995. Introducing Youth Culture in its Own Right: The State of the Art and New Possibilities. In: Youth Cultures: A Cross-Cultural Perspective, Amit-Talai, V. and H. Wulff (Eds.), Routledge, London, ISBN-10: 0415109833.

Wyneken, G., 1963. Was ist Jugendkultur? [What is youth culture?]. in: Grundschriften der deutschen Jugendbewegung, Düsseldorf, Kindt, W. (Ed.), Diederichs (Original work published 1913), Germany. In: Janssen. J., M. Dechesne and Kippenberg, A.V., 1999. The psychological importance of youth culture: A terror management approach. Youth Society, 31: 152-67. 